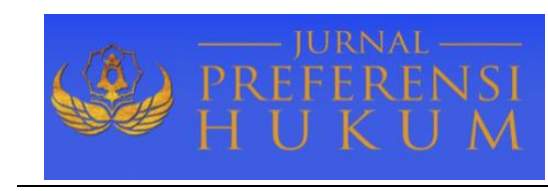

Jurnal Preferensi Hukum | ISSN: XXXX | E-ISSN: XXXX

Vol. 1, No. 2 - September 2020, Hal. 67-71| Available Online at https://www.ejournal.warmadewa.ac.id/index.php/juprehum

DOI: http://doi.org/10.22225/jph.v1i2.2343 .67-71

\title{
PENYELESAIAN PERKARA PELANGGARAN HAK ATAS MEREK
}

\author{
I Gede Mahendra Juliana Adiputra, Ida Ayu Putu Widiati, Ni Made Puspasutari Ujianti \\ Fakultas Hukum Universitas Warmadewa, Denpasar-Bali, Indonesia
}

\begin{abstract}
Abstrak
Adanya persaingan mengakibatkan pemilik merek asli merasa dirugikan karena hasil penjualannya menjadi menurun. Apabila seseorang akan menggunakan merek pihak lain dibolehkan asalkan meminta izin kepada pemilik merek dulu. Pemilik dapat memberikan hak merek kepada orang lain tersebut yang disepakati dalam sebuah perjanjian. Rumusan masalah dalam penelitian ini sebagai berikut: bagaimana perlindungan hukum hak atas merek dan bagaimana penyelesaian pelanggaran hak atas merek. Metode penelitian yang digunakan dalam penelitian ini adalah penelitian hukum normatif. Hasil pembahasan dalam penelitian ini sebagai berikut: Perlindungan hukum hak atas merek telah diatur Undang-undang Nomor 20 Tahun 2016 tentang Merek dan Indikasi Geografis, dalam ketentuan Undang-undang tersebut dengan tegas dinyatakan apabila sudah didaftarkan dalam Undang-undang bahwa hak merek sudah dilindungi. Sanksi yang dikenakan terhadap pelaku tindak pidana hak merek adalah dengan dikenakan denda Rp. 20.000.000,- (dua puluh juta rupiah) dengan syarat jika denda tidak dibayar akan dikenakan pidana kurungan selama 6 (enam) bulan. Penyelesaian perkara merek dapat dilakukan melalui lembaga- lembaga yang dapat dipergunakan untuk menyelesaikan sengketa merek antara lain: Alternatif Penyelesaian Sengketa, Arbitrase dan Pengadilan. Alternatif penyelesaian sengketa menginginkan agar para pihak yang bersengketa dapat menyelesaikan sengketanya sendiri yang bertujuan untuk memperoleh kesepakatan bersama, jika kesepakatan tersebut gagal, bisa mengambil jalan arbitrase yaitu para pihak yang bersengketa untuk bisa menyelesaikan sengketa ke lembaga arbitrase berdasarkan perjanjian, selanjutnya, jika arbitrase yang berhasil tindakan terakhir adalah melalui pengadilan yaitu peradilan niaga yang mempunyai kewenangan mengadili sengketa merek.
\end{abstract}

Kata Kunci: Pelanggaran; Perkara merek; Penyelesaian

\begin{abstract}
The existence of competition causes the original brand owner to feel disadvantaged because the sales result has decreased. It is permissible for someone to use another party's mark as long as they ask permission from the trademark owner first. The owner can give trademark rights to other people as agreed in an agreement. The formulation of the problem in this research is as follows: how is the legal protection of trademark rights and how to resolve violations of trademark rights. The research method used in this research is normative legal research. The results of the discussion in this study are as follows: Legal protection of the right to a trademark has been regulated by Law Number 20 of 2016 concerning Trademarks and Geographical Indications, in the provisions of the Law it is expressly stated that if it has been registered in the law that the right to a trademark has been protected. The sanction imposed on the perpetrator of the crime of trademark rights is a fine of Rp. 20,000,000, - (twenty million rupiah) on condition that if the fine is not paid, he will be subject to imprisonment for 6 (six) months. Settlement of trademark cases can be carried out through institutions that can be used to resolve trademark disputes, including: Alternative Dispute Resolution, Arbitration and Courts. Alternative dispute resolution wants the disputing parties to resolve their own dispute with the aim of obtaining a mutual agreement, if the agreement fails, can take arbitration, namely the disputing parties to be able to resolve the dispute to the arbitration institution based on the agreement, furthermore, if the arbitration is successful the last action is through the court, namely the commercial court which has the authority to adjudicate trademark disputes.
\end{abstract}

Keywords: Violation; Brand case; Settlement

\section{PENDAHULUAN}

Merek akan terlihat ternilai di masyarakat jika diikuti dengan kualitas barang bagus. Produsen yang memperhatikan barang yang akan dijual mudah dipakai, dan tahan lama, seperti barang berupa pulpen 
tersebut, jika mudah dipakai, enak buat menulis, tintanya tidak cepat habis, tidak mudah rusak, pasti para pembeli akan merasa senang. Barang produksi yang bagus akan memberikan kesenangan pada pembelinya, pasti selalu diincar oleh masyarakat. Biasanya barang yang kualitasnya baik harganya lebih mahal karena bahan dasarnya juga tergolong bagus sehingga masyarakat dapat memakluminya karena sudah seimbang. Masyarakat merasa tidak rugi membeli barang dengan harga yang tinggi apabila mutunya benar-benar terjamin (Miru, 2007). Selanjutnya yang kedua adalah dengan merek yang dipilihnya seorang konsumen merasa dirinya lebih bergengsi. Apabila yang dipilihnya merek yang sudah terkenal di masyarakat, merasa gengsinya lebih tinggi dibandingkan dengan menggunakan merek yang belum terkenal. Terlebih lagi jika dibandingkan dengan menggunakan produk yang tidak bermerek (Djubaedillah, 2003).

Sebuah merek dapat menjadi terkenal di masyarakat karena selain iklannya dipasang di sejumlah media, juga karena kualitas barangnya bagus. jika sudah seperti itu biasanya apabila itu masuk bahan pokok akan banyak dikonsumsi oleh masyarakat. Dengan banyaknya barang yang terjual di pasaran akan mendapatkan keuntungan untuk pemilik merek itu. Pada umumnya merekmerek yang sudah dikenal di masyarakat dan barangnya tergolong laris di pasaran menjadi incaran pihak lain untuk ditiru. Motivasinya mereka ingin mendompleng ketenaran merek dan ikut serta meraih keuntungan secara tidak wajar. Biasanya barang yang dijual dengan merek tiruan kualitasnya rendah dan harganya lebih murah (Djubaedillah, 2003). Dalam perjalanan waktu terjadi penggantian Undang-undang Merek yang mempengaruhi sistem cara memperoleh hak atas merek. Undang-undang Nomor 21 Tahun 1992 tentang Merek sebagai pengganti Undang-undang Nomor 21 Tahun 1961 menganut sistem konstitutif. Pendaftaran merek sebagai cara memperoleh hak atas merek. Merek yang tidak didaftarkan tidak dilindungi oleh undang-undang (Margono, 2011; Rahayu., 2019). Sistem konstitutif tetap dianut sampai sekarang walaupun Undang-undang Nomor 19 Tahun 1992 tentang Merek diubah dengan Undang- undang Nomor 15 Tahun 2001 tentang Merek dan sekarang telah diganti dengan Undang-undang Nomor 20 Tahun 2016 tentang Merek dan Indikasi Geografis. Hal tersebut secara jelas dan tegas dipaparkan dalam penjelasan resmi Undang-undang Republik Indonesia Nomor 20 Tahun 2016 tentang merek dan indikasi geografis menekankan sebagai berikut: Pengaruh globalisasi di segala bidang kehidupan masyarakat, baik di bidang sosial, ekonomi, maupun budaya semakin mendorong laju perkembang perkembangan perekonomian masyarakat. Di samping itu, dengan semakin meningkatnya perkembangan teknologi informasi dan sarana transportasi, telah menjadikan kegiatan disektor perdagangan baik barang maupun jasa mengalami perkembangan yang sangat pesat. Kecenderungan akan meningkatnya arus perdagangan barang dan jasa tersebut akan terus berlangsung secara terus menerus sejalan dengan pertumbuhan ekonomi nasional yang semakin meningkat. Dengan memperhatikan kenyataan dan kecenderungan seperti itu, menjadi hal yang dapat dipahami jika ada tuntutan kebutuhan suatu pengaturan yang lebih memadai dalam rangka terciptanya suatu kepastian dan perlindungan hukum yang kuat. Apalagi beberapa negara semakin mengandalkan kegiatan ekonomi dan perdagangannya pada produk yang dihasilkan atas dasar kemampuan intelektualitas manusia. Mengingat akan kenyataan tersebut, merek sebagai salah satu karya intelektual manusia yang erat hubungannya dengan kegiatan ekonomi dan perdagangan memegang peranan yang sangat penting.

Kegiatan perdagangan barang dan jasa melintasi batas wilayah negara. dikarenakan cara mendaftakan merek internasional menjadi salah satu sistem yang harus dapat dipergunakan untuk melindungi merek nasional di seluruh dunia. untuk pendaftaran merek internasional berdasarkan protocol Madrid menjadi sarana yang pasti membantu pelaku usaha nasional untuk mendaftarkan mereknya di luar negeri dengan biaya yang tidak mahal. Pelanggaran merek akan menurun apabila kesadaran hukum terutama bagi para pengusaha atau pedagang meningkat, dengan cara membuat merek sendiri tanpa menjiplak merek lain. Berdasarkan penjelasan diatas dapat dirumuskan permasalahan dalam penelitian ini yaitu bagaimana perlindungan hukum hak atas merek serta bagaimana penyelesaian pelanggaran hak atas merek. Sesuai dengan penelitian terdahulu oleh (Lasut, 2019) menyatakan bahwa cara penyelesaian sengketa atas pelanggaran merek dapat dilakukan apabila pemilik merek telah terdaftar dan/atau penerima lisensi merek yang telah terdaftar, kemudian mengajukan gugatan terhadap pihak lain yang secara tanpa hak menggunakan merek yang mempunyai persamaan pada pokoknya atau keseluruhannya.

Secara menyeluruh penelitian ini dilaksanakan untuk mengetahui penyelesaian perkara pelanggaran hak atas merek sesuai dengan peraturan perundang-undangan yang mengaturnya 
sedangkan secara khusus penelitian ini bertujuan untuk mengetahui perlindungan hukum hak atas merek dan untuk mengetahui penyelesaian pelanggaran hak atas merek.

\section{METODE PENELITIAN}

Metode penelitian yang digunakan adalah teknik normatif. Yaitu dengan menjelaskan permasalahan yang ada dan melanjutkan pembahasan berdasarkan teori-teori hukum dan kemudian dikaitkan dengan aturan perundang-undangan yang ada dalam praktek hukum. Dalam penelitian ini digunakan pendekatan perundang-undangan (statue approach) dan pendekatan konseptual (conseptual approach). Dalam penelitian ini terdapat bahan-bahan hukum yang terdiri dari: (1) Bahan hukum primer yaitu bahan-bahan hukum yang mengikat, meliputi: Undang-undang Dasar Negara Republik Indonesia Tahun 1945, Undang- undangNomor 20 Tahun 2016 tentang Merek dan Indikasi Geografis. Bahan hukum sekunder berupa semua publikasi tentang hukum yang bukan merupakan dokumen-dokumen resmi. Publikasi tentang hukum meliputi buku-buku teks, kamus-kamus hukum, jurnal-jurnal hukum, dan komentar-komentar atas putusan hukum (Marzuki, 2007). Pengumpulan bahan hukum dilakukan dengan cara membaca, mempelajari, memahami, dan menganalisis buku atau literatur, ketentuan perundang-undangan, makalah, majalah, ataupun informasi dalam bentuk lain seperti diperoleh dari internet, berhubungan erat dengan obyek kajian atau materi penelitian, kemudian dilakukan pencatatan dan pengutipan bagian yang penting.

\section{HASIL DAN PEMBAHASAN}

\section{Perlindungan Hukum Hak atas Merek}

Dari penggantian Undang-undang Merek tersebut terdapat perbedaan yang dianggap paling mencolok adalah digantinya sistem dalam memperoleh hak atas merek. Sistem deklaratif yang dianut dalam Undang-undang Merek 1961 diganti dengan sistem konstitutif dalam Undang-undang Merek 1992. Sistem konstitutif dipandang lebih memberikan jaminan kepastian hukum dibandingkan dengan sistem deklaratif. pendapatan hak atas merek dalam sistem deklaratif dianggap tidak kuat karena didasarkan atas pemakai pertama merek bukan karena pendaftaran. Pendaftaran merek hanya mengakibatkan pendapat pemiliknya sebagai pemakai pertama merek. Sedangkan dalam sistem konstitutif pendaftar pertama merek dipastikan sebagai pihak yang berhak atas merek (Intelektual, n.d.; Marzuki, 2007).

Kekurangan sistem deklaratif itulah yang mendorong digantinya Undang-undang Merek 1961 dengan Undang-undang Merek 1992 yang menggunakan sistem konstitutif. Tidak dapat dikesampingkan begitu saja sepanjang berlakunya Undang-undang Merek 1961 banyak sengketa merek yang mempersoalkan siapa yang berhak atas merek yang sama. Sehubungan dengan itu (Gautama, 1997) mengatakan, apa yang merupakan persamaan pada pokoknya atau keseluruhannya dengan merek orang lain, tidak mudah diselesaikan dengan begitu saja, karena ini adalah suatu penilaian yang pada hakikatnya harus ditentukan oleh instansi pengadilan.

Setelah Undang-undang Merek 1992 berjalan kurang lebih lima tahun, kemudian Undang-undang tersebut dilakukan perubahan dengan Undang- undang Nomor 14 Tahun 1997 tentang Perubahan Undang-undang Nomor 19 Tahun 1992 tentang Merek (disebut Undang-undangMerek 1997). Perubahan Undang-undang ini tidak sampai mengganti Undang-undang Merek 1992 akan tetapi perubahannya hanya sekedar mengubah sebagian pasal-pasalnya saja karena Undang-undang tersebut perlu menyesuaikan dengan ketentuan yang ada dalam Trade Related Aspecs of Intelectual property Rights (TRIPs). Penyesuaian itu dilakukan sehubungan dengan negara kita telah meratifikasi Persetujuan pembentukan Organisasi Perdagangan Dunia (Agreement Establishing The World Trade Organization) dengan Undang-undang Nomor 7 tahun 1974 sebagai kosekuensi Indonesia ikut menandatangani Uruguay Round.

Meskipun Undang-undang Merek 1992 telah dilakukan perubahan dengan Undang-undang Merek 1997, namun para pembentuk Undang-undang yaitu Dewan Perwakilan Rakyat dan pemerintah pada akhirnya mengganti Undang-undang tersebut dengan Undang-undang Nomor 15 Tahun 2001 tentang Merek yang telah diganti dengan Undang-undang Nomor 20 Tahun 2016 tentang Merek dan Indikasi Geografis dengan pertimbangan bahwa Indonesia telah mengadopsi perjanjian dan aturan yang tidak tertulis secara internasional sehingga peranan merek menjadi penting terutama dalam menjaga persaingan usaha yang sehat. Adanya perubahan dan penggantian Undang-undang merek tersebut (Gautama dan Winata) mengatakan bahwa hal tersebut sebenarnya sudah berulangkali 
dilakukan, supaya memenuhi kewajibannya karena negara kita telah mengesahkan persetujuan tentang organisasi perdagangan dunia (World Trade Organization atau WTO) dengan Undang-undang Nomor 7 Tahun 1994 tentang Pengesahan Agreement Establishing The World Organization (Gautama, 1997).

\section{Penyelesaian Pelanggaran Hak atas Merek}

Walaupun pada kenyataannya telah terjadi penggantian Undang- undang merek, akan tetapi materi yang diatur di dalam Undang-undang Nomor 20 Tahun 2016 tentang Merek dan Indikasi Geografis pada prinsipnya sama dengan materi dalam Undang-undang Merek 1992 sebagaimana diubah dengan Undang-undang Merek 1997 dan Undang-undang Merek Tahun 2001. Tujuan penggantian Undangundang seperti dijelaskan dalam Penjelasan Umum Undang-undang Nomor 20 Tahun 2016 tentang Merek dan Indikasi Geografis untuk menciptakan pengaturan merek dalam satu naskah (single text) sehingga lebih memudahkan masyarakat untuk menggunakan Undang-undang tersebut. Kemudahan yang dimaksudkan itu tampak apabila dibandingkan dengan menggunakan Undang-undang Merek 1992 yang diubah dengan Undang Merek 1997 dan Undang-undang Merek Tahun 2001, karena masyarakat harus memakai kedua Undang-undang tersebut dan harus mengetahui mana peraturan yang diubah dan mana peraturan yang masih tetap seperti semula. Kemudian perbedaan yang nampak dari penggantian Undang-undang tersebut antara lain adalah yang menyangkut proses penyelesaian permohonan pendaftaran merek. Selain itu dalam Undang-undang Merek 2001 penyelesaian sengketa merek dilakukan di pengadilan niaga yang merupakan badan peradilan khusus.Dengan adanya perubahan dan penggantian Undang-undang merek sebagaimana tersebut di atas, maka peraturan yang berlaku mengenai merek sekarang ini adalah Undang-undang Nomor 20 Tahun 2016 tentang Merek dan Indikasi Geografis.

Apabila yang terjadi jalan menuju perdamaian mengalami jalan buntu, dimana para pihak yang berperkara saling berbeda pendapat dan masing-masing pihak bersikukuh tetap pada pendiriannya, sehingga kelanjutannya meminta bantuan penyelesaian kepada pihak ketiga. Biasanya pihak yang merasa dilanggar haknya menyelesaikan dengan mengajukan gugatan ke pengadilan.

Sebagaimana dibahas di atas penyelesaian perkara adalah tergantung kepada pemilihan para pihak yang berperkara. Berdasarkan peraturan Undang- undang yang berlaku di negara kita terdapat 3 (tiga) lembaga yang dapat digunakan untuk menyelesaian perkara, yaitu jalan lain menyelesaian Sengketa, Arbitrase, Pengadilan, dan Para pihak yang bersengketa bisa memilih satu di antara ketiga lembaga tersebut.

a. Alternatif Penyelesaian Sengketa (APS)

Lembaga APS diatur di dalam Bab II Undang-undang No. 30 Tahun 1999 tentang Alternatif Penyelesaian Sengketa dan Arbitrase, yang menghendaki agar para pihak yang bersengketa dapat menyelesaikan sengketanya sendiri yang tujuannya tidak lain adalah untuk memperoleh kesepakatan atau perdamaian.

Menggunakan lembaga APS untuk menyelesaikan sengketa bahwa para pihak memang sudah berkehendak untuk menyelesaikan di luar pengadilan dengan maksud agar perdamaian dengan sungguh-sungguh dapat tercapai. Undang-undang No. 30 Tahun 1999 mengatur dengan jelas dan tegas tentang tata cara untuk mencapai kesepakatan menuju perdamaian. Sebelum Undangundang ini dilahirkan usaha perdamaian yang dilakukan oleh pihak bersengketa mengikuti caranya sendiri, sehingga tidak ada cara yang seragam untuk menjadi pegangan bagi masyarakat. Dengan adanya Undang-undang tersebut, maka dengan lembaga APS digunakan sebagai alat untuk mencapai perdamaian.

b. Arbitrase

Arbitrase adalah penyelesaian perkara dengan menggunakan arbiter atau wasit. Lembaga ini diatur dalam Bab III dan seterusnya Undang-undang Nomor 30 Tahun 1999. Para pihak yang bersengketa untuk dapat menyelesaikan sengketa ke lembaga arbitrase wajib berdasarkan perjanjian. Mereka dengan sengaja membuat perjanjian untuk menyelesaikan sengketa ke arbitrase. Selain dapat memilih arbiter sendiri, mereka juga dapat memilih tempat penyelenggaraan persidangan arbitrase.

Sebelum lahirnya Undang-undang No. 30 Tahun 1999 di negara kita, peraturan arbitrase berlaku ketentuan Pasal 615 sampai dengan pasal 651 Reglement op de Rectverdering (Rv) Staatsblad 1847: 52 dan Pasal 377 Het Herziene Indonesisch Reglement (HIR) Staatsblad 1941: 44 dan Pasal 705 Rechtsreglement Buitengewesten (R.Bg) Staatsblad 1927: 27. Adapun objek sengketa 
yang dapat diselesaikan melalui arbitrase adalah sengketa- sengketa di lingkungan perdagangan dan hak yang menurut hukum dan peraturan perundang-undangan dikuasai semuanya oleh pihak yang bersengketa. Dengan melihat objek sengketa tersebut maka pelanggaran hak atas merek merupakan sengketa yang dapat diselesaikan melalui arbitrase karena merek ruang lingkupnya berada di bidang perdagangan.

c. Pengadilan

Pengadilan merupakan lembaga yang melakukan kekuasaan kehakiman dan bertugas memeriksa dan mengadili suatu perkara. berhubungan dengan itu berdasarkan Undang-undang Nomor 48 Tahun 2009 tentang Kekuasaan Kehakiman terdapat 4 (empat) lingkungan badan peradilan yang berada di bawah Mahkamah Agung. Untuk peradilan umum wewenangnya adalah mengadili perkara perdata dan perkara pidana. Peradilan Militer mengadili perkara pidana yang pelakunya berstatus anggota TNI (Tentara Nasional Indonesia). Peradilan Agama mengadili perkara perdata khususnya menyangkut sengketa di bidang perdata Islam. Sedangkan Peradilan Tata Usaha Negara mengadili sengketa tata usaha negara. Badan-badan di atas yang mempunyai hak mengadili sengketa merek yaitu Peradilan Umum. dari tahun 1999 negara Indonesia mempunyai pengadilan niaga yang merupakan pengadilan perkara kepailitan dan perkara HAKI.

\section{SIMPULAN DAN SARAN}

\section{Simpulan}

Perlindungan hukum hak atas merek telah diatur Undang-Undang Nomor 20 Tahun 2016 tentang Merek dan Indikasi Geografis, dalam ketentuan Undang-undang tersebut dengan tegas dinyatakan apabila sudah didaftarkan dalam Undang-undang bahwa hak merek sudah dilindungi. Sanksi yang dikenakan terhadap pelaku tindak pidana hak merek adalah dengan pidana denda Rp. 20.000.000,(dua puluh juta rupiah) dengan syarat jika denda tidak akan dikenakan dengan pidana kurungan selama 6 (enam) bulan. Berikutnya Penyelesaian perkara merek dapat dilakukan melalui lembagalembaga yang dapat dipergunakan untuk menyelesaikan sengketa merek antara lain: Alternatif Penyelesaian Sengketa, Arbitrase dan Pengadilan. Alternatif penyelesaian sengketa menginginkan supaya para pihak yang bersengketa bisa menyelesaikan sengketanya sendiri yang bertujuan untuk memperoleh kesepakatan bersama, jika kesepakatan tersebut tidak tercapai, diambil cara arbitrase yaitu para pihak yang bersengketa untuk dapat menyelesaikan sengketa ke lembaga arbitrase berdasarkan perjanjian, selanjutnya, jika arbitrase yang berhasil tindakan terakhir adalah melalui pengadilan yaitu peradilan niaga yang mempunyai kewenangan mengadili sengketa merek. Sesuai dengan kesimpulan tersebut diatas, dapat penulis sampaikan

\section{Saran}

Perlindungan hukum merek di Indonesia perlu mengikuti perkembangan zaman karena sesuai dengan keadaan yang ada sudah pasti ada perubahan yang perlu diperbaharui serta dalam penyelesaian sengketa merek hendaknya lebih tepat mempergunakan lembaga Alternatif Penyelesaian Sengketa.

\section{DAFTAR PUSTAKA}

Djubaedillah, M. J. \& R. (2003). Hak Milik Intelektual. PT. Citra Aditya Bakti.

Gautama, S. (1997). Hukum Merek Indonesia. Alumni Bandung.

Intelektual, D. J. K. K. H. dan H. R. (n.d.). Memahami Merek.

Lasut, P. W. (2019). Penyelesaian Sengketa Gugatan atas Pelanggaran Merek Menurut Undang-

Undang Nomor 20 Tahun 2016 tentang Merek dan Indikasi Geografis. Lex Et Societatis, 7(1).

Margono, S. (2011). Hak Milik Industri: Pengaturan dan Praktik di Indonesia. Ghalia Indonesia. Marzuki, P. M. (2007). Penelitian Hukum. Kencana Prenada Media Grup.

Miru, A. (2007). Hukum Merek Cara Mudah Mempelajari Undang- undangMerek. PT Raja Grafindo Persada.

Rahayu., A. A. S. W. S. B. (2019). Studi Kasus Penerapan Prinsip Pendaftaran First To File Pada Pembatalan Merek Cap Mawar (Putusan Mari Nomor: 512 K/Pdt.Sus-Hki/2016). Syiah Kuala Law Journal, 3(2). 